Review article

DOI: $10.22363 / 2313-1683-2019-16-2-237-244$

UDC 159.99

\title{
How Psi Chi Became the International Honor Society in Psychology
}

\author{
John M. Davis \\ Texas State University \\ 601 University Drive, San Marcos, Texas 78666, United States of America
}

\begin{abstract}
Psi Chi, the National Honor Society in Psychology, was founded in 1929 during the Ninth International Congress of Psychology at Yale University, the first convened in the United States. Eighty years later, in 2009, Psi Chi officially became the International Honor Society in Psychology. Now, on the tenth anniversary of that change, it seems fitting to tell the story of how Psi Chi became the International Honor Society in Psychology. Several former leaders contributed significantly to this international expansion. My involvement began when I was elected to the position of Vice-President for the Southwestern Region. During my two terms as VP, I advocated for an international perspective whenever possible. After completing my second term as VP, I was elected to the position of PresidentElect and began writing short articles for Eye on $P_{s i}$ Chi that suggested a more international perspective. As President, I continued the effort to encourage Psi Chi to become international. I developed ten proposed amendments to the Psi Chi Constitution that, if approved, would transition Psi Chi from a national to an international society. During the last business meeting of my term as Past-President in August 2008, the Council approved all ten amendments. The final step, a national vote by the Psi Chi chapters in April of 2009, also approved all ten amendments and made the changes official. Now, in 2019, Psi Chi celebrates the tenth anniversary of the transition from a national to an international society with 23 chapters in 15 countries or U.S. territories.
\end{abstract}

Key words: Psi Chi; National Honor Society in Psychology; International Honor Society in Psychology; international psychology

Psi Chi, the National Honor Society in Psychology, was founded in 1929 during the Ninth International Congress of Psychology at Yale University, the first to be convened in the United States. Two years earlier, in 1927, two U.S. graduate students at the University of Kansas, Edwin Newman and Frederick Howell "Bud" Lewis, had envisioned and begun planning for an honor society for psychology (Hogan \& Sexton, 2000). Their vision culminated in the founding of the Society on September 4, 1929 when representatives from 14 departments of psychology approved a charter for the Society. Between that date and the end of 1929, another eight chapters signed, and these 22 chapters were designated charter chapters (Hogan \& Sexton, 2000).

(C) Davis J.M., 2019

This work is licensed under a Creative Commons Attribution 4.0 International License 
The Ninth International Congress of Psychology convened at Yale University attracted more than 1000 registered individuals. In addition to 722 U.S. and 104 foreign regular members, 106 wives of members and 129 guests registered for the Congress. This was the largest attendance up to that date. Interestingly, it was held on the $50^{\text {th }}$ anniversary of the establishment of the first formal experimental laboratory in psychology by Wilhelm Wundt in Leipzig in 1879. Attendees at the Congress included a number of prominent psychologists including Ivan P. Pavlov of Russia, Wolfgang Kohler of Germany, Carl Spearman of England, and Edward L. Thorndike of the United States (Rosenzweig et al., 2000). Eighty years later, in 2009, Psi Chi chapters voted to change the Constitution in order to make Psi Chi officially the International Honor Society in Psychology.

Now, on the tenth anniversary of that international expansion, it seems fitting to tell the story of how Psi Chi, the National Honor Society in Psychology became Psi Chi, the International Honor Society in Psychology. I like to think that before it became a reality, many people imagined the possibility of expanding Psi Chi beyond U.S. borders.

In fact, several former leaders of Psi Chi had extensive international experience and interests. Those leaders contributed in various ways to the conditions that led to this international expansion. Some of them included former Psi Chi presidents. For example, Rogers Russell, President 1962 - 1964, held faculty positions in Australia and maintained university connections in New Zealand, England, and Sweden. During his presidency, Psi Chi designated 1962-1963 the Society's International Year. Russell later served as President of the International Union of Psychological Sciences (Rosenzweig et al., 2000). During Charles Spielberger's presidency (1980-1983), Psi Chi promoted and assisted study abroad for Psi Chi members. Spielberger later served as President of the International Association of Applied Psychology. During Slater Newman's presidency (1997-1998), his President's column for the Summer, 1998 issue of Eye on Psi Chi was titled Internationalizing Psi Chi. That issue had the title "Internationalizing Psi Chi" on the front cover along with the word "Psychology" in many languages. President Martha Zlokovich (2003-2004) studied in Germany, promoted international psychology (Zlokovich \& Harris, 2004), and rejoined Psi Chi in 2008 as Executive Director.

In 1994, Harold Takooshian surveyed psychologists in countries outside the United States to learn if there were psychology honor societies in those countries. Later that year at the annual convention of the International Council of Psychologists in Lisbon, Portugal, he presented his results and discussed how psychologists in other countries could establish honor societies (Takooshian, 1994). He and I met at that presentation and discovered that we had similar interests in Psi Chi and international psychology. During Harold Takooshian's presidency (1998-1999), he and Past-President Slater Newman noted that "our discipline would benefit much from the international contact likely to ensue should Psi Chi chapters be established outside the US" (Takooshian \& Newman, 1998, p. 369).

The process of transforming Psi Chi from the National to the International Honor Society in Psychology took several years. My involvement began when I was encouraged to accept the nomination for a position on the then Psi Chi National Council as Representative for the Southwestern Region of Psi Chi. I was serving as the faculty advisor of the Psi Chi Chapter at Texas State University at that time. Our chapter invited Past President of Psi Chi, Jesse Purdy, to give the keynote address at one of our induction ceremonies. During the social activities afterwards, Past President Purdy, who was chair 
of the nominating committee, asked if I would accept a nomination for the position of Psi Chi Vice-President for the Southwestern Region. I agreed, the Texas State University Chapter nominated me, and I was elected. At that point in 2000, I began imagining how Psi Chi might be expanded internationally.

Along with my deep interest in serving students, I have a deep and lifelong interest in learning about the people of the larger world beyond U.S. borders. In addition to the United States, I have lived in Germany, China, England, and South Africa and traveled to many other countries to present or conduct research. When I was growing up in rural Oklahoma, my parents invited visiting missionaries to stay at our small farm home while they were in our area. Also, my parents arranged with the foreign student advisor at nearby Oklahoma State University for our family to meet international students. We got to know two young men from Nigeria quite well who were studying engineering. They frequently stayed with us on weekends and went to church with us. Thus, even as the opportunity to serve students in a larger arena by running for a position on the Psi Chi National Council seemed attractive, I also began to develop the idea that I could introduce Psi Chi to a more international perspective (Davis, 2000).

After being elected, I served a two-year term on the National Council (renamed Board of Directors when Psi Chi became international) as Vice-President for the Southwestern Region spanning the period from August 2000 to August 2002. I was re-elected and served a second term from August 2002 to August 2004. During that time period I learned much about Psi Chi and developed a great respect for and a strong commitment to the Society. Then I was elected to a term as President-elect from August 2005 to August 2006, transitioned to the office of President in August 2006, and to Past-President in August 2007. I completed my duties as Past-President in August 2008.

I have a lifelong commitment to expanding the science of psychology to the whole human population, the whole human family. During my two terms as Vice-President on the National Council, I advocated for an international perspective whenever possible. I initiated an international task force and a formal liaison position between Psi Chi and the American Psychological Association Committee on International Relations in Psychology (CIRP). I served in that position as the first liaison and presented reports to CIRP about Psi Chi activities. My first report to CIRP was presented on April 7, 2006. In that report I briefly described Psi Chi's founding and membership, the Society's purpose, and some of its activities. I also noted that the Psi Chi Constitution permitted the chartering of international affiliate chapters - Psi Chi had approved that addition to the Constitution in 1985. At that time, however, Psi Chi only had one international affiliate chapter, University of Victoria in Canada. I concluded the report by referring to an article I had published in Eye on Psi Chi in which I examined some practical benefits as well as challenges involved in Psi Chi becoming an international honor society in psychology.

When, a year after completing my second term as Vice-President for the Southwestern Region, I was elected to the position of President-elect of Psi Chi, I took the opportunity to begin writing short articles for Eye on Psi Chi that expressed the importance of psychology taking a more international perspective. I also shared with a few colleagues my intention to take Psi Chi international when I assumed the role of Society President. My first column as President and my first public indication of my desire to see Psi Chi become 
international was titled "Promoting Psi Chi and advancing the science of psychology" (Davis, 2006, Fall). In that article, I predicted that in five years Psi Chi would be the international honor society in psychology. My subsequent Presidential columns all dealt with international issues (Davis, 2006, Winter; Davis, 2007, Spring; Davis, 2007, Summer; Davis, 2007, Winter).

It was not a simple nor an easy process. At the time, there were other priorities that could not be ignored. The Psi Chi National Office in Chattanooga was in transition. The Executive Director of many years had passed away unexpectedly, and her replacement had other priorities and wanted her commitment to the position to be short term. Psi Chi had grown rapidly over the years and the National Council decided that the Executive Director position should be divided into two positions - office management and top executive - with a new requirement that the top executive be a psychologist with teaching experience. National searches had to be conducted to fill both positions. Also, Psi Chi had recently added the responsibility of planning and holding a National Leadership Conference and that became the responsibility of the President. Organizing Psi Chi programing at the annual conventions of the American Psychological Association and the Association for Psychological Science were also responsibilities of the President, Executive Council, and National Council members.

Psi Chi was extremely fortunate to be able to hire Virginia Andreoli Mathie as the new Executive Officer responsible for facilitating the work of Psi Chi elected officers. At my request, Ginny Mathie prepared a great deal of background research to educate the members of the National Council on past efforts to expand Psi Chi in a more international direction. She also helped prepare detailed analyses of the changes to the Psi Chi Constitution that would need to be considered in order to move Psi Chi to become the international honor society.

During my term as President, I brought a motion before the National Council to approve the effort to change Psi Chi to become international. The vote was close but the motion was not approved. However, the motion had the value of opening the discussion at the Council level and of identifying the positions of the Council members. It also had the value of bringing to light the concerns of those members who did not support such a move. Some Council members simply did not want to approve the idea until they had seen it developed in more detail. Other Council members wanted to wait for other countries to develop their own honor societies

Following that Council meeting, Ginny Mathie and I continued to work on the initiative and sought to address more fully what would need to be revised in the Psi Chi Constitution as well as what work would need to be carried out to recruit Psi Chi chapters in other countries if Psi Chi did become international. We continued this work into my term as Past President. During that period, I took the extensive work that Ginny Mathie had prepared and synthesized more than twenty constitutional changes into ten proposed constitutional amendments that captured all the constitutional changes that would be needed to transform Psi Chi from a national to an international honor society.

During the final business meeting of my term as Past President in August 2008, these proposed amendments were a major portion of the agenda of the National Council. At that point, Vincent Prohaska was Psi Chi President. Ginny Mathie had retired in June and Martha S. Zlokovich had replaced her in the role of Executive Director. With President 
Prohaska presiding, the National Council passed all ten proposed amendments in their original, or in one case slightly modified, form by a two-thirds majority vote to change Psi Chi from a national to an international society. Council approval, however, was not the final step. Changes to the Psi Chi Constitution also require approval by a national vote of the Psi Chi chapters.

The constitutional amendments were published in the Fall 2008 issue of Eye on Psi Chi with a request for letters either in support or in opposition. The Spring 2009 issue published the amendments again with seven letters of support, two letters in opposition, and a statement summarizing the National Council's reasons for supporting the proposed amendments. The accompanying instructions noted that chapters had 60 days to vote using the online voting portal, that ballots were due in the National Office by April 1, 2009, and that approval by three-fourths of the voting chapters was required to amend the Psi Chi Constitution (Amendments: Letters of support, 2009).

The final step of amending the Constitution resulted in changing Psi Chi from the National to the International Honor Society in Psychology, changing the National Council to the Board of Directors, the National Office to the Central Office, and National Awards to Society Awards. The constitutional amendments also eliminated international affiliate chapter status and made international affiliate chapters full Psi Chi chapters. Again, all ten proposed amendments to the Constitution were approved, resulting in the four affiliate chapters Psi Chi had established by that time - three new ones under Ginny Mathie's guidance in Ireland, Puerto Rico, and the US Virgin Islands - automatically becoming full chapters.

Changing the Constitution, however, was only the beginning. Psi Chi then embarked on a process of re-branding the Society's image including publications, merchandise, chapter supplies, the Psi Chi website, and more. The Board charged the new Executive Director, Martha S. Zlokovich, with working with faculty outside the U.S. 50 states to increase the number of international chapters (Zlokovich, 2012). An International Committee was formed to begin the development of a comprehensive international expansion strategic plan and budget for the Board of Directors to consider at their January 2011 business meeting. The committee consisted of Psi Chi President, Alvin Wang, and former presidents John Davis, Harold Takooshian, and Executive Director Martha Zlokovich. I continued to encourage Psi Chi members to pursue greater international understanding and to prepare for their future within a global context (Davis, 2011).

Now in 2019 Psi Chi celebrates the tenth anniversary of the transition from national to international. In the ten years since that change, Psi Chi has expanded internationally and now has 23 approved chapters in 15 countries or U.S. territories (Barbados, Canada, Ecuador, Egypt, Guam, Guatemala, Ireland, Malaysia, New Zealand, Puerto Rico, Russian Federation, Trinidad and Tobago, United Kingdom, and US Virgin Islands). As we look to the future, I believe that Psi Chi is well positioned to contribute to greater international understanding and to a perspective that is more inclusive of the entire human population.

\section{Acknowledgements}

I thank Carol J. Davis, Harold Takooshian, and Martha S. Zlokovich for providing valuable comments on earlier versions of this article. 


\section{References}

Amendments: Letters of support. (2009, Spring). Eye on Psi Chi, 13(3), 10-13.

Davis, J.M. (2000, Spring). Four international organizations in psychology: An overview. Eye on Psi Chi, 4(3), 33-37. Retrieved from: https://doi.org/10.24839/1092-0803.Eye4.3.33

Davis, J.M. (2006, Winter). Should Psi Chi become the International Honor Society in Psychology? Eye on Psi Chi, 10(2), 36-37, 51.

Davis, J.M. (2006, Fall). Promoting Psi Chi and advancing the science of psychology. Eye on Psi Chi, 11(1), 4, 36. Retrieved from: https://doi.org/10.24839/1092-0803.Eye11.1.4

Davis, J.M. (2007, Winter). The psychology of growing up global. Eye on Psi Chi, 11(2), 4. Retrieved from: https://doi.org/10.24839/1092-0803.Eye11.2.4

Davis, J.M. (2007, Spring). US higher education in a global context: A user's guide. Eye on Psi Chi, 11(3), 4. Retrieved from: https://doi.org/10.24839/1092-0803.Eye11.3.4

Davis, J.M. (2007, Summer). Strategies for planning and setting goals. Eye on Psi Chi, 11(4), 4. Retrieved from: https://doi.org/10.24839/1092-0803.Eye11.4.4

Davis, J.M. (2011, Spring). A user's guide to U.S. higher education in a global context. Eye on Psi Chi, 15(3), 10-11. Retrieved from: https://doi.org/10.24839/1092-0803.Eye15.3.10

Hogan, J.D., \& Sexton, V.S. (2000). Psi Chi, the National Honor Society in Psychology. In S.F. Davis \& M. Wertheimer (Eds). An oral history of Psi Chi, The National Honor Society in Psychology. Chattanooga, TN: Psi Chi.

Newman, L.E. (1998, Summer). Internationalizing Psi Chi. Eye on Psi Chi, 2(4). Retrieved from: https://doi.org/10.24839/1092-0803.Eye2.4.80

Rosenzweig, M., Holtzman, W., Sabourin, M., \& Belanger, D. (Eds). (2000). History of the International Union of Psychological Science (IUPsyS). London: Psychology Press. Retrieved from: https://doi. org/10.4324/9780203987797

Takooshian, H. (1994). Psi Chi: Impact of a student honor society on a nation's psychology. Paper presented at the annual meeting of the International Council of Psychologists, Lisbon, Portugal.

Takooshian, H., \& Newman, S.E. (1998). Recognizing excellent psychology students. International Journal of Psychology, 33, 367-369.

Zlokovich, M.S. (2012, Fall). Psi Chi and international psychology. Eye on Psi Chi, 17(1), 6. Retrieved from: https://doi.org/10.24839/1092-0803.Eye17.1.6

Zlokovich, M.S., \& Harris, B. (2004, Winter). Where in the world is Wilhelm Wundt? Eye on Psi Chi, 8(2). Retrieved from: https://doi.org/10.24839/1092-0803.Eye8.2.4

\section{Article history:}

Received: 27 April 2019

Revised: 13 May 2019

Accepted: 15 May 2019

\section{For citation:}

Davis, J.M. (2019). How Psi Chi Became the International Honor Society in Psychology. RUDN Journal of Psychology and Pedagogics, 16(2), 237-244. http://dx.doi.org/10.22363/2313-16832019-16-2-237-244

\section{Bio Note:}

John M. Davis, Ph.D., is Graduate Professor of Psychology and Honorary Professor of International Studies at Texas State University. His research focuses on interpersonal, intergroup, and 
international relations. He has served as Faculty Advisor of the Texas State Chapter of Psi Chi for many years, as Psi Chi Southwestern Regional Vice-President for two terms, and as Psi Chi President (2006-2007). As President-elect, President, and Past-President, he initiated and led the successful effort to transform Psi Chi from a national to an international honor society. E-mail: jd04@txstate.edu

Обзорная статья

\title{
Как Psi Chi стало Международным психологическим обществом почета
}

\author{
Дж.М. Дэвис \\ Техасский государственный университет \\ Соединенные Штаты Америки, 78666, Техас, Сан Маркос, University Drive, 601
}

Psi Chi, Национальное психологическое общество почета, было основано в 1929 году на IX Международном психологическом конгрессе, который впервые проходил в Соединенных Штатах Америки в Йельском университете. Спустя восемьдесят лет, в 2009 году, Psi Chi официально стало Международным психологическим обществом почета. В десятую годовщину этого преобразования представляется уместным рассказать о процессе трансформации Psi Chi в международное общество, чему и посвящена данная статья.

Несколько бывших лидеров Psi Chi внесли значительный вклад в процесс его интернационализации. Наше участие началось с избрания на должность вице-президента Psi Chi по Юго-Западному региону США. Одной из задач на этом посту на протяжении двух сроков было развитие международных перспектив общества. После завершения второго вице-президентского срока и избрания на должность президента Psi Chi мы начали писать короткие статьи для журнала Eye on Psi Chi, в которых предлагали развивать международные перспективы общества, а также продолжили курс на интернационализацию общества. Нами были разработаны и предложены десять поправок к Конституции Psi Chi, которые, в случае их принятия, должны были превратить Psi Chi из национального в международное общество. Во время нашей последней деловой встречи уже в качестве бывшего президента в августе 2008 года Совет утвердил все десять поправок. И, наконец, путем общенационального голосования отделения Psi Chi в апреле 2009 года также одобрили все десять поправок, что сделало изменения в Конституции официально принятыми. В сентябре 2019 года Psi Chi отмечает десятую годовщину своей интернационализации, имея 23 отделения в 15 странах мира.

Ключевые слова: Psi Chi; Национальное психологическое общество почета; Международное психологическое общество почета; международная психология

\section{Благодарности}

Мы благодарим Кэрол Дэвис, Гарольда Такушьяна и Марту Злокович за ценные комментарии к более ранним версиям этой статьи. 


\section{История статьи:}

Поступила в редакцию: 27 апреля 2019

Принята к печати: 15 мая 2019

\section{Для цитирования:}

Davis J.M. How Psi Chi Became the International Honor Society in Psychology (Kaк Psi Chi стало Международным психологическим обществом почета) // Вестник Российского университета дружбы народов. Серия: Психология и педагогика. 2019. Т. 16. № 2. С. 237-244. http://dx.doi.org/10.22363/2313-1683-2019-16-2-237-244

\section{Сведения об авторе:}

Дэвис Джкон M., Ph.D., профессор кафедры психологии и почетный профессор международных исследований в Техасском государственном университете. Его исследовательские интересы связаны с изучением межличностных, межгрупповых и международных отношений. В течение многих лет был советником отделения Psi Chi штата Tехас, в течение двух сроков занимал должность регионального вице-президента Psi Chi Юго-Западного региона США и был президентом Psi Chi в 2006-2007 гг. Один из инициаторов и непосредственный участник процесса трансформации Psi Chi из национального в международное психологическое общество почета. E-mail: jd04@txstate.edu 